\title{
Application with Geoinformation for Control of Damage in Public Property
}

\author{
Patricia G. Carvalho, Claudio G. Bernardo, Claudio G. Duque, Otavio M. Fiedein, and Vitor B. Bueno
}

\begin{abstract}
Aiming to improve population life quality of the Brazilian Federal District, and using concepts of Information Architecture and Geoinformation, this research presents a mobile application with objective of facilitating practice of denouncing damages to the public patrimony, locating geographically and cataloging this damage so that public sector is notified and population perceives changes and actions taken by the government. Mobile platforms are becoming other channels through which citizens can report information in real time. Federal District currently has 3 million inhabitants and 5.8 thousand $\mathrm{km}^{2}$, and it is common to see areas without sanitation, without asphalts and with damages to public patrimony such as fallen poles, squares vandalized, abandoned buildings, among others. By means of geolocation and damage mapping, Volunteered Geographic Information and this mobile application allows citizen to make complaints and ask government to do maintenance, being a new tool to help environment and human being life.
\end{abstract}

Index Terms-Volunteered geographic information, geoinformation, mobile application, public patrimony.

\section{INTRODUCTION}

In cities there are problems related to public patrimony, be it lack of sanitation, neglect or even problems caused by accidents or natural disasters, characterizing as damage to urban public patrimony everything that damages, denigrates, and in extreme cases, destroy some good inside of urban area [1]. The Federal District is one of the 27 federative units of Brazil. It is located in the Center-West Region, being the smallest Brazilian federal unit and the only one that has no municipalities; it is divided into 31 administrative regions, totaling an area of 5.8 thousand $\mathrm{km}^{2}$. See its map in Fig. 1. In its territory, is located the federal capital of Brazil, Brasília, that is also the seat of the government of the Federal District (FD). Today, in this region, complaints of damages in public patrimony are made in a precarious way, by means of telephone calls, sending of e-mails or personally in offices of public sector.

Disorders are common everywhere, whether they are broken sidewalks, fallen poles, knocked down walls or others. In order to provide a service so that these complaints reach competent agencies quickly, improving the efficiency to resolve them and prioritizing most serious problems, the research group devised a mobile application, so that the citizen can make complaints, and send them directly to a database, where the competent bodies can identify and the citizen can follow existing complaints as well as follow the solution of your complaint.

Manuscript received October 29, 2017; revised January 22, 2018.

Patricia Carvalho is with Escola Fiocruz de Governo, Brazil (e-mail: patriciagcarvalho@yahoo.com.br).
Some literatures present other systems of help in controlling and solving problems, such as Colab.re [2], which provides its services in Rio de Janeiro City and has already been tested by its citizen. It was proposed a system development that allows denouncing damages in public patrimony, through a mobile application, and locating them so that people are aware of their community's problems. Application also presents a general list of complaints that can be seen by competent authorities and citizen.

Reference [3] presents a research that evaluates the strengths, weaknesses, opportunities, and threats for the American selected real cases: "Field Photo," "CoCoRaHS," "OakMapper," "What's Invasive!", "Leafsnap," "U.S. Green Infrastructure Reporter", and "Nebraska Wetlands". Based on these case studies, the results indicate that active, loyal and committed users are key to ensuring the success of citizen science projects. Online and off-line activities should be integrated to promote the effectiveness of public engagement in environmental management.

In Information Science, the essence of information is that it should be registered and treated to allow a future recovery [4]. According to [5] Information Organization occurs in an information system consisting of interrelated components to collect, to process and to disseminate information, under of a management of a commissionaire, appearing with a feedback mechanism to assist review, improvement and adaptation to the environment in which it operates.

Information Science, especially Information Organization line, can support discussions about process of representing Geoinformation. Construction of Geoinformation demonstrates that the greater the number of modes involved in process of geoinformation representation, the less uncertainty involved in approximation with its real meaning and, mainly, with the concept of geographic phenomenon analyzed [6]. Some researchers care about geocommunication and information design, and seek how decide to transmit content A or content B to another person on a systematic and controlled basis [7]. There were apparently no existing theories, models etc. capable of identifying and choosing the content of information in systematic and controlled fashion with a view to achieving geo-communication - with a view to achieving agreement regarding issues and their location.

This application was developed using Java programming languages [8], for development was used NetBeans IDE [9], web pages were builded using Cascading Style Sheets (CSS) and HTML [10], [11]; used Scrum development technique [12], the operating system chosen was Android System [13], using Android Studios [14], [15] and chosen database was MYSQL [16].

Google Maps system allows, through its Application 
Program Interfaces - API, that sites and applications use their data, adapting it in best way [17]. This research group chose it as the most popular mapping application on Android operating system [13], identifying that most Brazilian users use it, in addition to having its resources more widely disseminated in programming forums [18]. An example of Google Maps use is shown in Fig. 2.

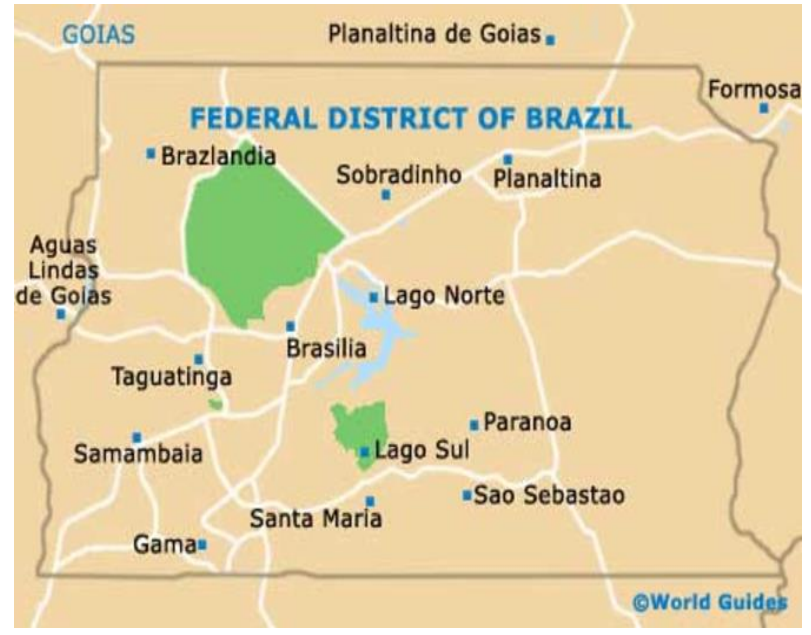

Fig. 1. Map of federal district of Brazil.

Because it is the most accessed social network in Brazil today, Facebook has several methods of verifying identity and veracity of information. For this application users identification was used authentication by Facebook.

\section{DAMAGES IN URBAN PUBLIC PATRIMONY OF BRAZILIAN FEDERAL DISTRICT}

Since the mid-twentieth century urbanization has been growing at ever-increasing speed, this means that large poles and urban centers are receiving more and more people coming and going from their jobs and daily chores, and with it vandalism and disregard for part of the population. It is very important maintain and clean centers with the highest traffic of people, and so governmental and private estates that need to undergo restoration. Time is the main agent on structures of any city. Depending on the material used in these constructions, whether they are sidewalks, benches, roads or even buildings, they all have a "lifetime", in another words, the time that this material will withstand and maintain its form in the face of weather, such as acid rain, temperature differences, storms and strong winds.

Another problem is social issue when certain location is depredated and needs repair or even rebuilding. This type of vandalism is recurring in many places, such as bus stops, traffic signs, parks, gardens, among many others. Finally, the last factor is accidents, those caused by phenomena of nature and those of traffic.

From this point, in some Brazilian states, applications have been developed where citizens can report occurrences in their communities. Normal system of reporting damages in urban public assets can be time-consuming and flawed, as it is subordinated to a series of regulations and bureaucracy. Through a mobile application, citizens can easily report and pass feedback to appropriate authorities through photos and comments regarding each occurrence [19].
Some good examples of such applications are Colab.re [2], which performs its function as a kind of "social network" between citizen and responsible governmental unit, allows citizen to supervise, suggest improvements and classify public institutions and services. Occurrences generated are accessed by responsible agencies in Rio de Janeiro State, so that it interacts with citizen in a transparent way and choose best decision [2]. Another system is TakeVista, which offers user greater freedom by allowing him/she to create own complaint categories using own hash tags, which can also be a problem since some malicious people can create fake and out-of-subject complaints, in addition to having no mechanism to directly inform government about complaints [20]; One more system available in Brazil is MeuAmbiente (My Environment, in Portuguese) [20] created to record occurrences of environmental crime and is a project of Amazonia Mais Institute [21], a non-profit organization whose objective is to cooperate with Amazonia sustainable development.
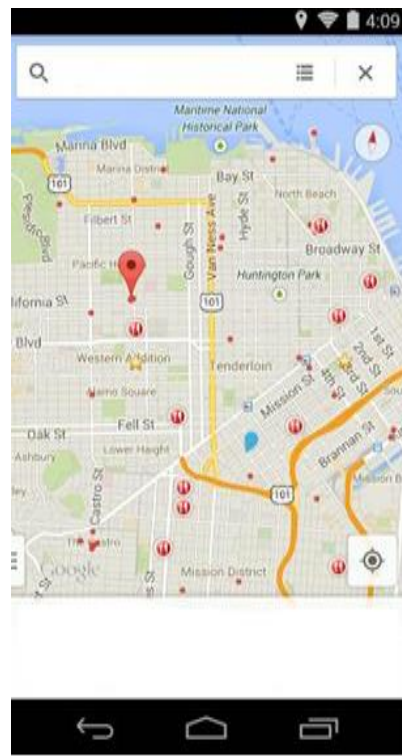

Fig. 2. Example of using Google Maps

Through these applications is possible making complaints of problems, but in Brazilian Federal District there is no service that receives these kind of complaints with geolocation of public damage having its detailed image.

Every idea about generate service where population can make voluntary denunciations for community well-being is linked to the movement, that unfortunately is little diffused in Brazil, called Volunteered Geographic Information (VGI), a movement that approaches concept of user generating content, which consists of volunteers who report in various tools geographic information existing in various locations around the world. Citizens regardless of their knowledge or expertise, are able to produce spatial information. Reference [19] affirms that crowd-sourcing, social, and geographic approaches have been proposed and later followed to develop appropriate methods to assess the quality measures and indicators of VGI, and they review various quality measures and indicators for selected types of VGI and existing quality assessment methods presenting a classification with current methods utilized to assess the quality of selected types of VGI. 
Other examples of various uses of VGI are WikiMapia sites, a mapping site that is powered by user community itself, and Google Map Maker, a Google tool that allows construction and updating of maps with help of users community.

Bringing VGI into a mobile application context means that the service will only work with help of volunteers who make denunciations and spread information, showing where the problems in their community are and how the solution process works. It is an urgent need to transfer complex environmental data to citizens' daily mobile devices, which will then allow them to participate in urban environmental management [3].

\section{Urban Complaint System}

Among various functions of FD Regional Administration, there is public services management. As a way of streamlining communication process between government and population, some tools were made available, among them, the Disque-Denúncia (complaint by phone, in Portuguese) available at http://www.ouvidoria.df.gov.br, in addition to place for face-to-face complaints. In Brazil, ombudsmanship is a space that acts as a bridge between population and public offices [22], [23]. It is a service open to citizens listen all demands, denunciations, suggestions and also praise for various services available to population, but according to Brazilian General Ombudsman, "an ombudsman should not act immediately". This is a problem that unfortunately citizen has to accept, because it is one of the rules that general ombudsman adopts, which ends up not satisfying population of their desire for agile resolution.

Upon receipt of a complaint, a record is generated in system and a protocol number is made available to citizen. Complaint is forwarded to a central where all records are filtered and redirected to responsible administration. Population can follow the progress of process through ombudsman's website. DF administrative regions have physical limits established by public authority, which define jurisdiction of governmental action, for purposes of administrative decentralization and coordination of public services [24].

Control process of complaints made in person in administrations basically consists of a paper form, in which citizen gives some details, such as location, date, and comments briefly on the subject of complaint. Soon after, this form is sent to responsible area and thus begins the process of analysis that is time consuming. However, although there is standardization and unification of coordination systems of public services by administrators, there are particularities in each one.

The control process done in administration is disorganized, since that form is filled in at time of complaint without any type of standardization. In spite of following the same idea of composition of other administrative regions, in the document simply a person writes briefly his complaint and delivery to administrative clerk. For complaints involving outsourced or related companies, the regional administration sends them daily to competent offices. The neglect of public power is common, since such regions do not have basic urban infrastructure, bringing irreversible damages, besides additional costs to citizens' life.

\section{APPLICATION WITH GEOINFORMATION FOR CONTROL OF DAMAGE IN PUBLIC PROPERTY}

A networked society, current state of study fields of Information Science (IS) in general, brings as an element of signification and presentation to world, to other and to other cultures, its location and description of their place. In same way that it presents itself, it also makes reading of other cultures from the way in which citizen describes its context and its representation of world, currently perfectly adjusted to its geographic location, that is to say, the geoinformation [6]. In case of geoinformation, representation of these contexts happens in production of cartographic mappings of varied scales, objectives and formats.

This application offers a service of complaints of damages in public patrimony, in which each problem is characterized as an occurrence. To file a complaint, user must go to location of the incident and take a picture of situation through application, then make a brief comment about the problem and finally the application will start Google Maps in background to get coordinates of place of complaint. Google Maps is an application that uses Global Positioning System (GPS) of user's cell phone, and based on his positioning in relation to satellites he is able to estimate user coordinates and thus indicate where the person is. Fig. 3 shows an example of positioning given by the GPS system.

Using this interaction with Google Maps, application collects exact coordinates of report and then records it. Through general occurrence list, generated by application, a person can see occurrences in his locality and in other cities of FD besides being able to vote on the occurrences that he deems relevant, and those with greater number of votes are first to appear in general list of occurrences, so that they can be better visualized as an easier and quick way of pointing out problems that must be corrected by responsible offices. Application has a filter in general list of occurrences so that user can only search for reports made in a specific location, such as his/her neighborhood.

This project was divided into two stages: front-end and back-end development. Android Studio tool [14] was also used in back-end, which is an integrated development environment to facilitate creation of applications for proper operating system, launched by Google in 2013, along with Android framework. In front-end step was implemented a visual part of the application, its screens and menus, as well as its logo and main color palette.

Application navigation starts from a login screen (Fig. 4). After logging user navigates to home screen where they have access to all menus and screens of application, being able to go back to previous page and home page at any time. In this screen Facebook asks user if he agrees to let application receive information from his profile to $\log$ in, and if user does not agree, the Login does not happen.

If user accepts one or none of permissions, application returns to Login screen and prompts user to accept permissions. After login, user goes to terms of use screen where it is mandatory to agree so that application can be used. In this step user is registered in database. Terms of use used were provided by Shopify generator [25] and adapted by researchers for service presented. Once user agree to terms of use, user goes to initial screen of application where it shows the list of all records made and with buttons for interaction. 
Fig. 5 shows the moment in which user recorded an occurrence. In this screen he/she can "scroll" image to one side and go to settings screen, where will choose which type of reports he/she wants to see beyond desired location of filters. By clicking on "+" button user is redirected to deny registration screen.

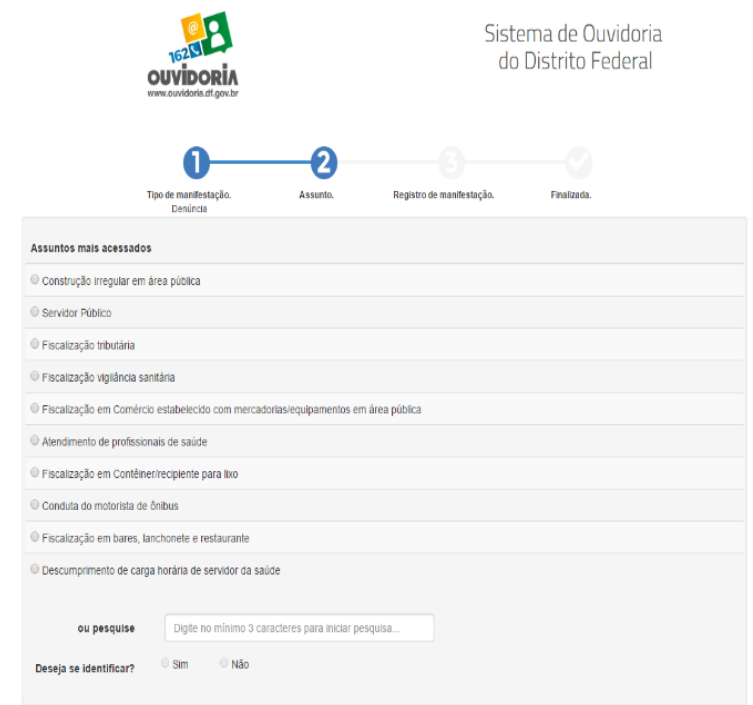

Fig. 3. Ombudsman website follow-up and complaint page (in Portuguese).

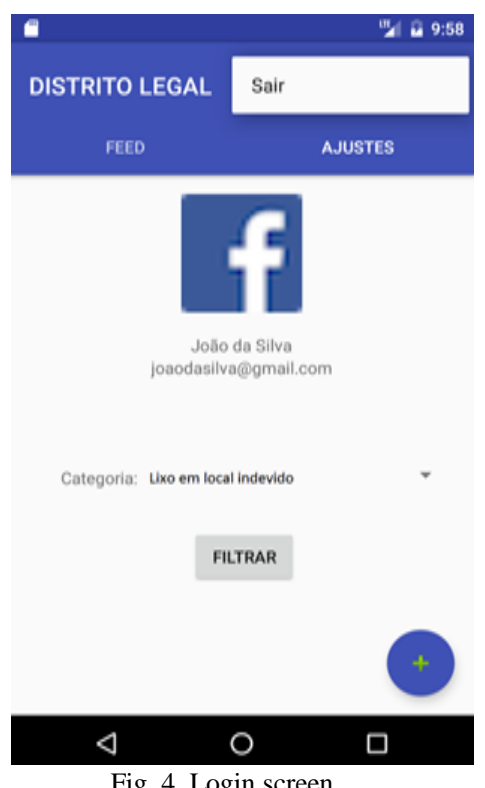

Fig. 4. Login screen.

In settings screen there is a filter with categories so that user only sees what he wants on home screen. There is also a profile with basic user information. On registration screen user enters damage description. selects a category, and takes photo or record a video (Fig. 6). Fields such as date and coordinates are taken in background by Google Maps and there is no user interaction with them.

\section{A. Categories of Damage}

Reporting categories to be used in this system must meet demand for occurrences. With this in mind, researchers chose to categorize them into groups, in order to create subdivisions from most common to most punctual, allowing also inclusion or modification of categories and new occurrences for categories already existing within the users' demand, as presented In Table I. Categories were selected according to demands known to developers.
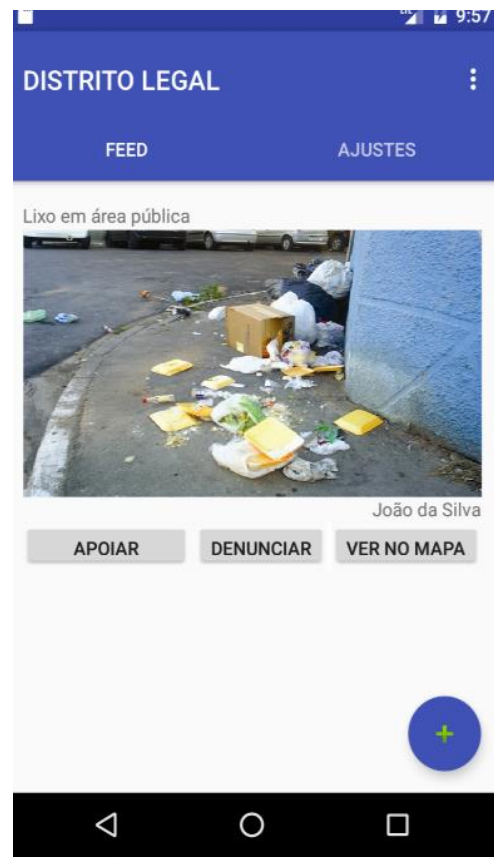

Fig. 5. Occurrence recorded.

\section{B. Records of Interviews}

A research was applied with title "Mapping Application for Denunciations of Damage in FD Public Patrimony" with following questions: a) what is your age group?; B) do you know of any means of communicating, reporting, complaining or criticizing a problem in your city to responsible office ? ; C) What is the operating system of your mobile phone?; D) how do you assess urgency of an application that facilitates by citizen a communication / reporting to public agency?

Of those interviewed people $45.5 \%$ did not know any means to report any problem to public sector, $37.4 \%$ answered that they already knew; about sense of urgency of an application, $57.4 \%$ understand it as urgent and $28.7 \%$ understand it as very urgent.

\section{CONCLUSION}

This paper presented a solution to help communication and location of damages in public patrimony, optimizing transparency and relationship between citizens and public sectors, improving quality of life in urban environment. Research has shown that, although there are ways to report such damages and to seek help of administrations, these means are not sufficient.

Population has no guarantee that public agencies are aware of problems or even if they are working to correct them, so with this application is possible help both sides making it a tool of public offices to categorize, list and locate damages, as well as help to improve, so that population can see results. Relationship between public sector and citizen should be clear and straightforward, but because of today's bureaucracy, many resources such as time and money can be wasted. This application proposes to citizens communicate more easily, in addition to make results achieved by government be seen by all. 


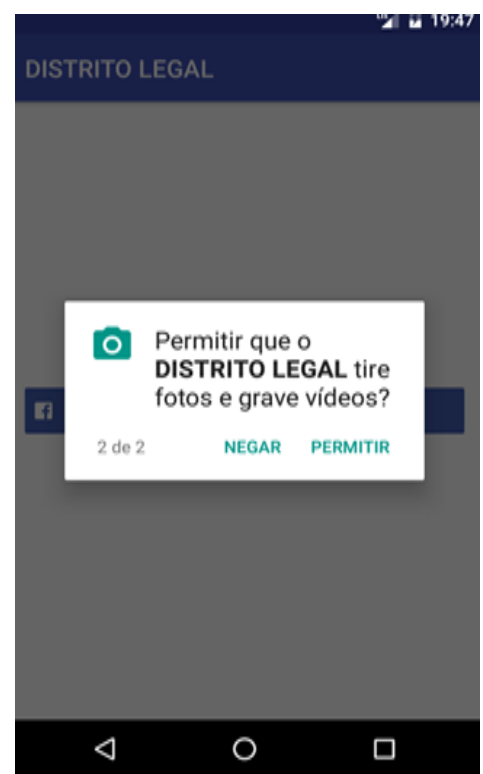

Fig. 6. Popup asking about photos \& videos.

Using appropriate programming language, a database and API available by Google Maps and Facebook, core parts of application have been developed, where some functionality will be implemented in future. Research group understands that application can be of great importance for improvement of urban area infrastructure, causing economy of public money, increasing population live quality, as well as an easier and faster way of public administrations to realize maintenance of urban areas.

TABLE I: CATEGORIES OF DAMAGES IN PUBLIC PATRIMONY

\begin{tabular}{|c|c|c|c|}
\hline & Lighting & & Pedestrians and cyclists \\
\hline 1 & Light pole off & 16 & Non-existent sidewalk \\
\hline 2 & Overhead light pole & 17 & $\begin{array}{l}\text { Sidewalk with hole } \\
\text { /irregular }\end{array}$ \\
\hline \multirow[t]{2}{*}{3} & $\begin{array}{l}\text { Field reflector / sport } \\
\text { court off }\end{array}$ & 18 & $\begin{array}{l}\text { Bicycle path with hole } \\
\text { /irregular }\end{array}$ \\
\hline & Water and sewage & 19 & $\begin{array}{l}\text { Pedestrian range nonexistent } \\
\text { / damaged }\end{array}$ \\
\hline 4 & Clogged culvert & 20 & Bad signposted bicycle path \\
\hline 5 & Unsealed culvert & 21 & Bicycles damaged \\
\hline 6 & Water leak & & Public transportation \\
\hline \multirow[t]{2}{*}{7} & Flood point & 22 & $\begin{array}{l}\text { Bus / subway station } \\
\text { damaged }\end{array}$ \\
\hline & $\begin{array}{l}\text { Cleanliness and } \\
\text { conservation }\end{array}$ & 23 & Damaged bus stop \\
\hline 8 & Broken trash can & & Urbanism \\
\hline 9 & $\begin{array}{l}\text { Garbage in undue } \\
\text { place }\end{array}$ & 24 & Broken traffic light \\
\hline \multirow[t]{2}{*}{10} & $\begin{array}{l}\text { Rubble accumulated } \\
\text { in an improper place }\end{array}$ & 25 & Broken sign plate \\
\hline & Nature & 26 & Lack of signaling board \\
\hline 11 & High bush & 27 & Damaged footbridge \\
\hline 12 & Pruning tree & 28 & $\begin{array}{l}\text { Damaged Community } \\
\text { Meeting Point }\end{array}$ \\
\hline 13 & Irregular burning & 29 & Damaged park \\
\hline 14 & Fallen tree & 30 & Damaged Decks \\
\hline 15 & $\begin{array}{l}\text { Waste in the lake / } \\
\text { stream }\end{array}$ & 31 & \\
\hline
\end{tabular}

Suggestions for Future Work

The researchers think about application improvements: photo standardized and stored in a photo bank, to facilitate occurrence information; location of record of similar occurrence and display a message asking if some of occurrences do not correspond to register that user wants to do, canceling registration or giving continuity to record, in order to avoid that an occurrence is registered more than once, and finally, presenting status with resolved or pending information.

\section{CONCLUSION AND Futures APPLICATIONS}

Mobile applications are useful tools in any context. If an application has, an objective of facilitating practice of denouncing damages in public patrimony it cans help to solve many cases to benefit population. Mobile platforms are becoming great channels through which citizens can report information in real time. A probable future application of this research could be spread its idea in many other cities, helping to improve connection between citizens and governments.

\section{ACKNOWLEDGMENT}

Patricia Gonçalves Carvalho acknowledges FAPDF Fundo de Apoio à Pesquisa do Distrito Federal - a Brazilian fund that supports researches in Federal District. This funding was published at DODF 138 , in Jul $7^{\text {th }}, 2017$, page 25. This research was part of Labor Completion of graduate students in Computer Science, 2nd half of 2016 in UNIP Universidade Paulista, campus Brasilia, Federal District, Brazil. Authors would like to thank Faculty of Information Science (UnB) and Institute of Exact Sciences and Technology (UNIP).

\section{REFERENCES}

[1] Jusbrasil. Destruction of Public Patrimony. [Online]. Available: http://www.justice.com/jurisprudencia/busca?q=DESTRUI\%C3\%87 $\% \mathrm{C} 3 \% 83 \mathrm{O}+\mathrm{DE}+\mathrm{BENS}+\mathrm{P} \% \mathrm{C} 3 \% 9 \mathrm{ABLICOS}$

[2] Colab.re. Making the city better is in your hand. [Online]. Available: http://www.colab.re/

[3] Z. Tang, Y. Zhou, H. Yu, Y. Gu, and T. Liu, Developing an Interactive Mobile Volunteered Geographic Information Platform to Integrate Environmental Big Data and Citizen Science in Urban Management Nebraska, USA: Springer International Publishing, 2017, pp. 65-81.

[4] C. G. Duque, "A proposal for an information retrieval system based on computational linguistics theories and ontology," Doctoral thesis, UFMG, Minas Gerais, Brazil, 2005.

[5] D. M. Batista, R. H. Araújo Jr, and E. Carlan, "The scope of information analysis," in Tours by Information Forest: Studies on Representation and Organization of Information and Knowledge (in Portuguese), Jaime Robredo \& Marisa Bräscher, eds. IBICT, Brasília, Brazil, 2010

[6] C. S. Sampaio and C. G. Duque, "One contribution of organization science for representation of geoinformation," XVII Encontro Nacional de Pesquisa em Ciência da Informação (XVII ENANCIB), Bahia, Brazil, 2016.

[7] L. Brodersen. (2017). Geo-communication and information design, meta-carto-semiotics. [Online]. 1(1). pp. 1-13. Available: http://ojs.meta-carto-semiotics.org/index.php/mcs/article/view/36

[8] IBM. (2016). Object-oriented programming on Java platform. [Online]. Available: https://www.ibm.com/developerworks/java/tutorials/j-introtojava1/

[9] Netbeans. (2016). NetBeans Community. [Online]. Available: https://netbeans.org/about/

[10] W3schools. (2016). CSS Demo - One HTML Page - Multiple Styles! [Online]. Available: https://www.w3schools.com/css/css_intro.asp

[11] W3C Web Design and Applications. (2016). [Online]. Available https://www.w3.org/standards/webdesign/htmlcss

[12] Scrum Methodology Scrum Methodology. (2016). [Online] Available: http://scrummethodology.com 
[13] Android Developers. Dashboards. (2016). [Online]. Available: https://developer.android.com/about/dashboards/index.html

[14] IMASTERS. (2016). Android studio: Advantages and disadvantages with respect to Eclipse. [Online]. Available: http://imasters.com.br/mobile/android/android-studio-vantagens-e-des vantagens-com-relacao-ao-eclipse/?trace $=1519021197 \&$ source $=$ singl

[15] INFOQ. (2016). Android developers are encouraged to migrate from Eclipse to Android Studio 1.0. [Online]. Available: https://www.infoq.com/br/news/2014/12/android-studio-1

[16] MySQL. (2016). Chapter 1 general information. [Online]. Available: https://dev.mysql.com/doc/workbench/en/wb-intro.html

[17] Tecmundo. (2016). Android studio: Google app authoring tool wins version $1.0 . \quad$ [Online]. Available: https://www.tecmundo.com.br/android/69111-android-studio-ferrame nta-criacao-apps-google-ganha-versao-1-0.htm

[18] Developers Google. Support options for Google Maps Android API. [Online]. Available: https://developers.google.com/maps/documentation/android-api/supp ort?hl=pt-br>

[19] A. Mobasheri, C. Capineri, M. Hakay, and A. L. Ali, "A review of volunteered geographic information quality assessment methods," International Journal of Geographical Information Science, pp. 139-167, Taylor \& Francis, 2016.

[20] Meuambiente. (2016). My Environment application. [Online]. Available: http://www.appmeuambiente.com.br

[21] Institute Amazonia Mais. [Online]. Available: http://www.amazoniamais.org.br/

[22] OUVDF. (2016). Federal District Ombudsman System. [Online]. Available: http://www.ouv.df.gov.br/\#/
[23] Controladoria Geral da União. (2016). Guidelines for the implementation of an ombudsman unit (in Portuguese). [Online]. Available:

http://www.cgu.gov.br/publicacoes/ouvidoria/arquivos/ogu-implantac ao-unidade-ouvidoria.pdf

[24] G. G. Costa, "The administrative regions of the federal district from 1960 to 2011," Doctorate Thesis, University of Brasília, Brazil, 2011.

[25] Shopify. (2016). Online Platform. [Online]. Available: https://pt.shopify.com/

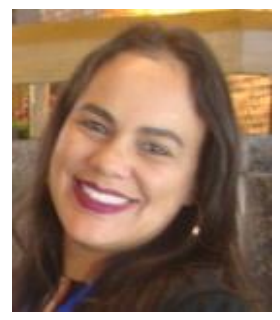

Patricia G. Carvalho is a $\mathrm{MsC}$ student in public health policies at Fiocruz / Brasília. She has got the MBA in hospital management. She is a specialist in family health and was graduated in nursing. She works as a technician of general coordination of Brazilian Health Ministry National Immunization Program. She is a professor at Nursing Department of Universidade Paulista - UNIP, Brasília campus; member of research group "Qualification of Strategic Management and Participated in SUS (Brazilian Health System)" project by Fiocruz/ Brasília. She acted by 6 years in Brazilian Health Ministry, as a higher level specialized technician. She coordinated Family Health Strategy in the Municipality of Montes Claros, Minas Gerais State. She worked as a teacher at Nursing Department of Montes Claros State University Unimontes. She was a supervisor of academic curricular internship at Faculdades Integradas Pitágoras in Montes Claros city. She acted as a nurse in family health strategy in the Municipality of Varzelândia - Minas Gerais State. 